\title{
Nutritional Modulation of Insulin-Like Growth Factor-I Expression in Early Postnatal Piglets
}

\author{
M. J. DAUNCEY, K. A. BURTON, AND D. R. TIVEY ${ }^{1}$ \\ Department of Cellular Physiology, The Babraham Institute, Cambridge, United Kingdom
}

\section{ABSTRACT}

The roles of intrauterine growth retardation, energy intake, and food composition in determining circulating and hepatic concentrations of IGF-I in early postnatal life have been determined. Intrauterine growth-retarded, small-for-gestational-age piglets were kept at thermal neutrality and fed sow's milk replacement formula to repletion at 6-h intervals between 2 and $14 \mathrm{~d}$ of age. When their appropriate-for-gestational-age littermates were pair-fed this intake, there were no significant differences in plasma or hepatic concentrations of IGF-I. Thus, under conditions of controlled food intake, prenatal undernutrition does not affect the postnatal expression of IGF-I. However, when appropriate-for-gestational-age piglets were fed to repletion at 6-h intervals over the $12 \mathrm{~d}$, they had a significantly greater hepatic IGF-I concentration $(p<0.002)$ and food intake $(p<0.001)$ than the small-for-gestational-age piglets, indicating a critical role for food intake regulation in catch-up growth. Striking differences in growth rate and

IGF-I is an important regulator of prenatal and postnatal growth (1-3) affecting both the mitogenesis and differentiation of a variety of cell types $(4,5)$. Although produced in many tissues, the liver is the major site of IGF-I synthesis, and the peptide circulates in plasma bound tightly to its high-molecular-weight binding proteins from which it is released by dissociation and binding to its receptor (6).

Regulation of the plasma concentration of IGF-I is via a complex interaction between nutrient balance, hormonal status, and stage of development (7). Studies in a wide range of mammalian species have demonstrated a positive correlation between birth weight and plasma concentration of IGF-I (8-11). In neonatal human infants and piglets, plasma IGF-I concentration increases significantly during the first 2 wk of postnatal life $(12,13)$. However, it is not clear whether prenatal undernutrition can influence the subsequent postnatal ontogeny of IGF-I

Received July 27, 1993; accepted January 2, 1994.

Correspondence and reprint requests: Dr. M. J. Dauncey, Department of Cellular Physiology, The Babraham Institute, Cambridge CB2 4AT, UK.

${ }^{1}$ Present address: Department of Animal Sciences, Waite Agricultural Research Institute, The University of Adelaide, Glen Osmond, South Australia.
IGF-I expression were also found between formula-fed, appropriate-for-gestational-age piglets compared with animals left with the sow. The latter grew much more rapidly $(p<0.0001)$ and had considerably higher levels of plasma IGF-I $(p<0.0001)$ despite similar hepatic IGF-I concentrations. Differences in plasma IGF-I may have been caused by the high level of IGF-I in maternal milk, by differences in hepatic synthesis and release, or by altered profiles of IGF binding proteins and hence in altered IGF-I clearance from plasma. The regulation of neonatal growth and development by IGF-I in maternal milk now needs to be investigated. (Pediatr Res 36: 77-84, 1994)

\section{Abbreviations}

SGA, small for gestational age

AGA, appropriate for gestational age

IGFBP, insulin-like growth factor binding protein

GH, growth hormone

expression. In some studies, plasma levels of IGF-I are reported to be greater in SGA than in AGA human infants postnatally $(14,15)$, whereas in others the opposite conclusion has been drawn (16). Discrepancies between studies in humans could arise because food intake was not controlled or because of genetic differences between subjects, which have been shown to be of importance in the neonatal pig (17).

Nutritional status exerts a direct influence on plasma IGF-I in many species including man, rat, and pig (18). In pigs aged $2-4 \mathrm{mo}$, it has been found that circulating and tissue levels of IGF-I are related to the energy available for growth rather than to the level of energy intake per se; IGF-I concentrations are reduced because of either a low energy intake or a high metabolic demand $(19,20)$. However, the extent to which a change in energy intake affects circulating and tissue levels of IGF-I in the early postnatal period is not known.

Many hormones and growth factors, including IGF-I, have been identified in milk from a number of species (21). By contrast, immunoreactive IGF-I is undetectable in milk replacement formulas used for feeding infants (22). Whether such a difference in milk composition can 
influence IGF-I expression in early postnatal life has not been determined.

The present study was therefore directed toward testing the hypothesis that birth weight, level of energy intake, and food composition can significantly influence the circulating and hepatic concentrations of IGF-I in early postnatal life. Studies were carried out in the neonatal pig, thus allowing careful control of food intake, ambient temperature, and genetic origin. Furthermore, not only does this species produce a naturally occurring form of intrauterine growth retardation, but it also makes a particularly good metabolic model for growth in children, because it has a similar critical temperature and zone of thermal neutrality (23). Part of this work has been the subject of a preliminary communication to the Physiological Society (24).

\section{METHODS}

\section{Animals}

Piglets from the Large White herd kept at The Babraham Institute were selected at birth according to body weight. An SGA animal was defined provisionally as one with a birth weight of $0.8 \mathrm{~kg}$ or less, whereas the AGA littermates had birth weights of approximately $1.4 \mathrm{~kg}$. Previous investigations had shown that, within the Institute herd, this method selects SGA as distinct from slightly small AGA animals (25). When birth weight is plotted against the cumulative sample proportion on normal probability paper, a litter without an SGA animal presents a single straight line, whereas SGA piglets appear as clear deviates from this line $(26,27)$.

Animals were left with the sow for the first $48 \mathrm{~h}$ of life to ensure the acquisition of adequate passive immunity from the colostrum. Thereafter, to enable close control of food intake, some piglets were left with the sow and others were kept in groups of two or three and maintained on a 12-h light:12-h dark cycle (lights on between 0800 and $2000 \mathrm{~h}$ ) under conditions of thermal neutrality by reducing the ambient temperature gradually from 34 to $30^{\circ} \mathrm{C}$ between 2 and $14 \mathrm{~d}$ of age. These animals were bottle-fed at 6-h intervals with a sow's milk replacement formula (Denkavit "Lifeline" Piglet Milk Replacer, British Denkavit, Poole, Dorset, UK). This formula is available as a complete milk replacer for piglets, and as such it can be used to rear piglets in the absence of the sow. Lifeline, per kg, contains $482 \mathrm{~g}$ of sugar (as lactose), 173 $\mathrm{g}$ of protein, $159 \mathrm{~g}$ of fat, $101 \mathrm{~g}$ of ash, $26 \mathrm{~g}$ of moisture, $2 \mathrm{~g}$ of starch, together with added vitamins, and it provides $17.8 \mathrm{~kJ}$ of energy per $\mathrm{g}$. It is reconstituted with water at a concentration of $150 \mathrm{~g}$ of powder per $1 \mathrm{~L}$ of mixed milk. Food intakes are presented in "Results" as $\mathrm{g}$ of diluted milk formula. Body weights of all formula-fed piglets were recorded daily before the meal at $1200 \mathrm{~h}$.

Treatments were continued until $14 \mathrm{~d}$ of age. Formulafed animals were then killed at approximately $6 \mathrm{~h}$ after the last meal by intracardiac injection of Lethobarb $[2 \mathrm{~mL}$ $20 \%$ (wt/vol) sodium pentobarbitone; Duphar Veterinary
Ltd., Southampton, Hampshire, UK] after sedation with Vetalar [0.5 mL ketamine hydrochloride $(100 \mathrm{mg} / \mathrm{mL})$; Parke-Davis Veterinary, Pontypool, Gwent, UK]. The liver was removed rapidly, washed in ice-cold $0.9 \%$ saline, cut into 3- to 4-g pieces, frozen in liquid nitrogen, and stored at $-40^{\circ} \mathrm{C}$. Blood samples were collected in heparinized tubes, and, after separation, plasma and whole blood were also stored at $-40^{\circ} \mathrm{C}$. Similar procedures were carried out with the sow-fed piglets at 2 wk of age. Apart from the conditions of normal animal husbandry, these animals were not disturbed for the $14 \mathrm{~d}$ of the study. After removal from the sow on d 14, they were kept at thermal neutrality until being killed approximately $4 \mathrm{~h}$ later. For all piglets, several hours had thus elapsed since the time of the last feed, thereby minimizing the effects of this last meal on a number of metabolic and endocrine parameters. Particularly important in this respect would be acute effects on plasma glucose and insulin, because these show a marked inverse relation with IGFBP-1, a protein that plays a role in minimizing the effects of cellular substrate deprivation $(1,6)$.

Study 1: prenatal nutrition. The aim of this study was to determine whether prenatal undernutrition can affect the subsequent postnatal expression of tissue and circulating levels of IGF-I. Investigations were carried out in seven litters of animals, each consisting of one SGA piglet and two AGA littermate controls of the same sex. A controlled amount of food was provided during the first $2 \mathrm{wk}$ of life, using the following procedure: the AGA animals were pair-fed the SGA piglet's ad libitum food intake at each feed (given at 6-h intervals). Two systems of pairfeeding were used: the first AGA animal was fed on the basis of metabolic body size (body weight ${ }^{0.67}$ ), whereas the second AGA animal was given the same absolute amount of food as its SGA littermate. The exponent 0.67 (i.e. food intake per $\mathrm{kg}^{0.67}$ ) was used in preference to 1.0 (i.e. food intake per $\mathrm{kg}$ ) because not only is heat loss related more closely to surface area (body weight ${ }^{0.67}$ ) than to mass (body weight ${ }^{1.0}$ ), but resting metabolic rate in animals of different size is related to a power of body weight that lies between two thirds and three quarters (23), and, for the young pig, the value is close to 0.67 . The three treatment groups were designated $\mathrm{SGA}_{\max }$, $A_{G A} A_{m b}$, and $A_{G A} A_{a b s}$. During the course of investigation, one SGA and one AGA animal had difficulties with feeding, and as a result failed to grow normally and had to be withdrawn from the study. A minimum of six litters in each treatment group was thus available for the final analysis.

Study 2: postnatal nutrition. In this study, the influences of both the quantity and composition of the early postnatal diet on tissue and plasma expression of IGF-I were investigated. Six pairs of AGA piglets were first studied: within each pair, one animal was fed ad libitum at 6-h intervals $\left(\mathrm{AGA}_{\max }\right)$ and its littermate was fed $50 \%$ of this intake on the basis of metabolic body size $\left(\mathrm{AGA}_{50 \%}\right)$. A further six piglets from three different litters were left with the sow throughout the 2-wk period of investigation 
$\left(\mathrm{AGA}_{\text {sow }}\right)$. Average litter size was 12 piglets, and apart from normal procedures of animal husbandry these animals were not disturbed during the first 2 wk of life. In this latter group, it was thus not possible to determine the rates of growth or food intakes of the animals because such procedures would have disrupted their normal feeding behavior.

\section{Estimation of Plasma and Tissue Contents of IGF-I}

The methods were based on those described previously $(28,29)$ and have been described in detail elsewhere (20). Briefly, IGF-I was first separated from its binding proteins under acid conditions for both plasma and tissues. For determining net tissue IGF-I content, the plasma-derived IGF-I trapped in the tissue was subtracted from the total tissue IGF-I; this involved determination of the $\mathrm{Hb}$ content of the tissues and the measurement of hematocrit. For RIA of IGF-I, the antiserum was antiIGF-I rabbit antiserum (UB3-189; generously given by Dr. L. Underwood and Dr. J. J. Van Wyk, via the Hormone Distribution Program of the National Institute of Diabetes and Digestive and Kidney Diseases through the National Hormone and Pituitary Program) for human IGF-I, and it was used in a 1:50 000 dilution. Standards were recombinant human IGF-I (Bachem Ltd., Saffron Walden, Essex, UK); human IGF-I was labeled by the Iodo-Gen method (Pierce Chemical Company, Pierce \& Warriner Ltd., Chester, Cheshire, UK) and used at an activity of $12000 \mathrm{cpm} / 100 \mu \mathrm{L}$. Separation of bound from free ${ }^{125}$ I-IGF-I was accomplished with a second antibody of sheep antiserum to rabbit IgG (kindly provided by Dr. C. G. Prosser, The Babraham Institute) used at a 1:5 dilution; normal rabbit serum was used as a carrier. These methods have been shown to yield a good recovery of IGF-I, with no interference in the assay from IGF binding proteins (30-32). To allow comparisons between studies 1 and 2 , all samples were analyzed within the same assay.

\section{Statistical Analysis}

The data were analyzed using version 5 of the statistical package Genstat (Lawes Agricultural Trust, Rothamsted, Hertfordshire, UK). Overall, there were six treatments: $\mathrm{SGA}_{\max }(\mathrm{A}), \mathrm{AGA}_{\mathrm{mbs}}(\mathrm{B}), \mathrm{AGA}_{\mathrm{abs}}(\mathrm{C}), \mathrm{AGA}_{\max }$ (D), $\mathrm{AGA}_{50 \%}(\mathrm{E})$, and $\mathrm{AGA}_{\text {sow }}(\mathrm{F})$, and these fell into three sets: A,B,C; D,E; and F, depending on whether or not the treatments could be paired within litters. Thus, the analysis for comparing treatments within the first set, A,B,C, was a randomized block design, where blocks were litters; analysis was similar for D,E. Treatment F was the only treatment that, of necessity, could be applied to a particular litter. Hence, comparisons between any two treatments within the above sets were made using paired $t$ tests, and comparisons between any two treatments that belonged to different sets were made by unpaired (Welch) tests; allowance was made for missing values where necessary. Welch tests were used because they do not assume equality of variance for the two treatments (33).

\section{RESULTS}

\section{Study 1: Prenatal Nutrition}

Growth rates (Table 1). At birth, the SGA piglets were approximately $50 \%$ lighter than their littermates. Although this difference in body weight tended to be maintained throughout the 2-wk period of investigation, the rate of weight gain of the SGA animals was greater than that of the AGA animals. This apparently greater efficiency of food conversion in the SGA animals compared with their pair-fed AGA littermates may have been a consequence, in part, of the lower level of physical activity observed in the SGA animals. As expected, the growth rate of the $\mathrm{AGA}_{\mathrm{mbs}}$ animals was slightly greater than that of the $A_{G A}$ abs group because of the slight difference in food intake.

Tissue and plasma levels of IGF-I (Fig. 1). At $14 \mathrm{~d}$ of age, there were no significant differences between the hepatic concentrations of IGF-I in SGA animals compared with their pair-fed AGA littermates, whether they were fed in relation to body size or fed the same amount of food. Similarly, there was no effect of prenatal undernutrition on the plasma level of IGF-I. In addition, no significant differences in plasma or tissue levels of IGF-I were observed between the two AGA groups on the different levels of food intake. This may have been because the difference in intake between the two groups was relatively small.

\section{Study 2: Postnatal Nutrition}

Growth rates (Table 2). Postnatal nutritional status had a significant effect on the growth of the AGA animals. At

Table 1. Study 1: prenatal nutrition*

\begin{tabular}{|c|c|c|c|c|c|c|}
\hline \multirow[b]{2}{*}{ Measurement } & \multirow{2}{*}{$\underset{\text { (group A) }}{\text { SGA }_{\text {max }}}$} & \multirow{2}{*}{$\begin{array}{c}\text { AGA }_{\text {mbs }} \\
\text { (group B) }\end{array}$} & \multirow{2}{*}{$\begin{array}{c}\text { AGA }_{\text {aba }} \\
\text { (group C) }\end{array}$} & \multicolumn{3}{|c|}{$p$ values } \\
\hline & & & & $A v s \mathrm{~B}$ & A vs C & $\mathrm{B} v s \mathrm{C}$ \\
\hline Birth weight $(\mathrm{kg})$ & $0.72 \pm 0.03$ & $1.40 \pm 0.04$ & $1.38 \pm 0.05$ & $<0.001$ & $<0.001$ & NS \\
\hline Food intake at $14 \mathrm{~d}\left(\mathrm{~g} / \mathrm{kg}^{0.67} / \mathrm{d}\right)$ & $240 \pm 14$ & $240 \pm 12$ & $167 \pm 14$ & NS & $<0.001$ & $<0.001$ \\
\hline Body weight at $14 \mathrm{~d}(\mathrm{~kg})$ & $1.05 \pm 0.06$ & $1.80 \pm 0.05$ & $1.71 \pm 0.05$ & $<0.001$ & $<0.001$ & NS \\
\hline Weight gain from 4 to $14 \mathrm{~d}(\mathrm{~kg})$ & $0.28 \pm 0.03$ & $0.36 \pm 0.04$ & $0.23 \pm 0.05$ & $<0.05$ & NS & $<0.005$ \\
\hline Increase in body weight from 4 to $14 \mathrm{~d}(\%)$ & $37 \pm 4$ & $25 \pm 3$ & $16 \pm 4$ & $<0.01$ & $<0.002$ & $<0.01$ \\
\hline
\end{tabular}

* Growth rates and food intakes of SGA piglets fed to repletion at 6-h intervals $\left(\mathrm{SGA}_{\max }\right)$ between 2 and $14 \mathrm{~d}$ of age and their AGA littermates, which were pair-fed the SGA intake on the basis of metabolic body size ( AGA $\left._{\text {mbs }}\right)$ or were given the same absolute amount of food (AGA $\left.A_{a b s}\right)$. Results are mean values \pm SEM. 

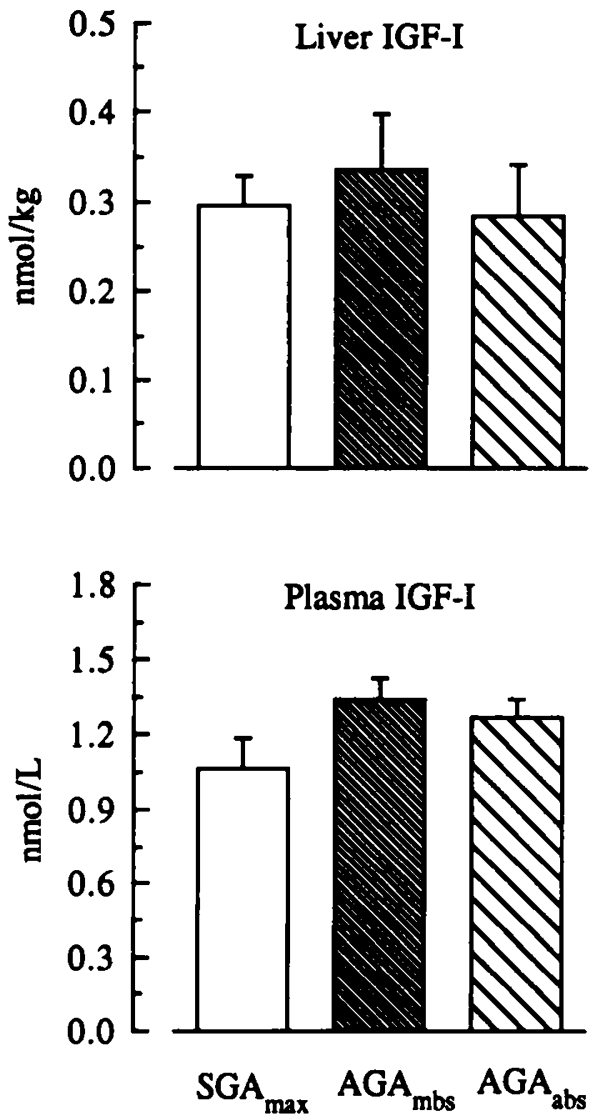

Figure 1. Study 1: Role of prenatal nutrition. Liver and plasma concentrations of IGF-I in SGA and AGA piglets aged $14 \mathrm{~d}$. SGA animals were fed a sow's milk replacement formula to repletion at 6-h intervals $\left(\mathrm{SGA}_{\max }\right)$ between 2 and $14 \mathrm{~d}$ of age. Two AGA animals were pair-fed the SGA intake, either as determined on the basis of metabolic body size or as the same absolute amount of food $\left(\mathrm{AGA}_{\mathrm{mbs}}\right.$ and $\mathrm{AGA}_{\mathrm{abs}}$, respectively). Results are mean values \pm SEM. None of the comparisons was statistically significant. For liver IGF-I, comparison between $\mathrm{SGA}_{\max }$ and $\mathrm{AGA}_{\max }$ (Fig. 2$)$ was significant $(p<0.002)$. Note different scales for $y$ axes in Figures 1 and 2.

Table 2. Study 2: postnatal nutrition*

\begin{tabular}{lccc}
\hline \multicolumn{1}{c}{ Measurement } & $\begin{array}{c}\mathrm{AGA}_{\max } \\
\text { (group D) }\end{array}$ & $\begin{array}{c}\mathrm{AGA}_{50 \%} \\
\text { (group E) }\end{array}$ & $p$ values \\
\hline Birth weight $(\mathrm{kg})$ & $1.35 \pm 0.02$ & $1.35 \pm 0.02$ & $\mathrm{NS}$ \\
Food intake at $14 \mathrm{~d}\left(\mathrm{~g} / \mathrm{kg}^{0.67} / \mathrm{d}\right)$ & $366 \pm 19$ & $183 \pm 8$ & $<0.005$ \\
Body weight at $14 \mathrm{~d}(\mathrm{~kg})$ & $2.46 \pm 0.07$ & $1.89 \pm 0.08$ & $<0.005$ \\
Weight gain from 4 to $14 \mathrm{~d}(\mathrm{~kg})$ & $0.81 \pm 0.06$ & $0.27 \pm 0.02$ & $<0.001$ \\
Increase in body weight from & $50 \pm 4$ & $17 \pm 2$ & $<0.001$ \\
4 to $14 \mathrm{~d}(\%)$ & & & \\
\hline
\end{tabular}

* Growth rate and food intakes of AGA piglets fed to repletion at 6-h intervals between 2 and $14 \mathrm{~d}$ of age $\left(\mathrm{AGA}_{\max }\right)$ or provided with $50 \%$ of this intake on the basis of metabolic body size $\left(\mathrm{AGA}_{5()_{\%}}\right)$. Results are mean values \pm SEM.

$14 \mathrm{~d}$ of age, the group fed sow's milk replacement formula to repletion at 6-h intervals $\left(\mathrm{AGA}_{\max }\right)$ were heavier $(p<$ $0.001)$ than their littermates restricted to half their food intake $\left(\mathrm{AGA}_{50 \%}\right)$. Growth rates during the period of study were also greater in the $\mathrm{AGA}_{\max }$ animals than in the $\mathrm{AGA}_{50 \%}$ animals. Particularly striking, however, was the finding that the animals left with the sow grew much more rapidly $(p<0.0001)$ than either of the groups fed the replacement formula. The average birth weight of piglets left with the sow was $1.4 \mathrm{~kg}$, and their average final body weight at $14 \mathrm{~d}$ was $5.0 \pm 0.2 \mathrm{~kg}$.

Tissue and plasma levels of IGF-I (Fig. 2). Restricting the amount of food eaten caused a significant reduction in the hepatic concentration of IGF-I $\left(\mathrm{AGA}_{\max }\right.$ versus $\mathrm{AGA}_{50 \%}, p<0.005$ ). However, there was no difference in relation to the type of milk consumed: the concentration of IGF-I in the liver of AGA piglets fed to repletion was not different from that of the piglets left with the sow $\left(\mathrm{AGA}_{\max }\right.$ versus $\left.\mathrm{AGA}_{\text {sow }}, p>0.5\right)$. By contrast, the plasma levels of IGF-I were markedly greater in the maternally fed compared with the formula-fed piglets $(p$ $<0.0001$ ). There was, however, no effect of quantity of food on the plasma concentration of IGF-I in the formulafed animals $\left(\mathrm{AGA}_{\max }\right.$ versus $\left.\mathrm{AGA}_{50 \%}, p>0.2\right)$.

\section{Comparisons between Studies 1 and 2}

Prenatal nutrition. Study 1 showed that, when comparisons are made between pair-fed SGA and AGA animals,
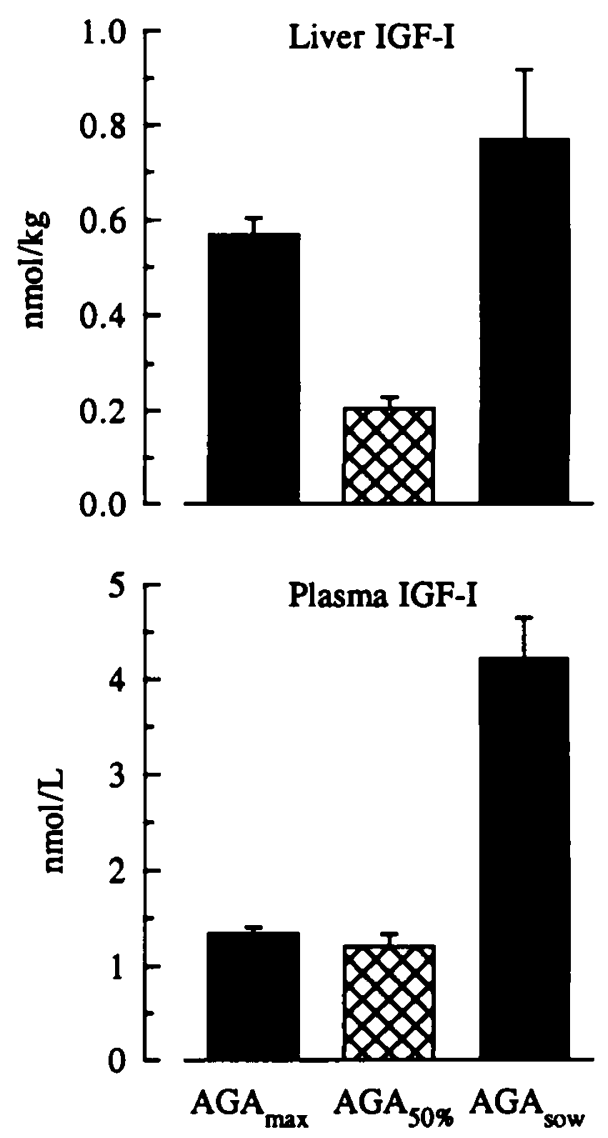

Figure 2. Study 2: Role of postnatal nutrition. Liver and plasma concentrations of IGF-I in AGA piglets aged $14 \mathrm{~d}$. Animals were fed a sow's milk replacement formula to repletion at 6 -h intervals between 2 and $14 \mathrm{~d}$ of age $\left(\mathrm{AGA}_{\max }\right)$, provided with $50 \%$ of this intake on the basis of metabolic body size $\left(\mathrm{AGA}_{50 \mathrm{r}_{\mathrm{c}}}\right)$, or left with the sow for the first $2 \mathrm{wk}$ of life $\left(\mathrm{AGA}_{\text {sow }}\right)$. Results are mean values $\pm \mathrm{SEM}$. The following comparisons were significant: for liver IGF-I, $\mathrm{AGA}_{50 \%}$ lower than $\operatorname{AGA}_{\max }(p<0.005)$ and $\operatorname{AGA}_{\text {sow }}(p<0.02)$; for plasma IGF-I, $\mathrm{AGA}_{\max }$ and $\mathrm{AGA}_{5(0 \%}$ lower than $\mathrm{AGA}_{\mathrm{sow}}(p<0.0001)$. For liver IGF-I, comparison between $\mathrm{SGA}_{\max }$ (Fig. 1) and $\mathrm{AGA}_{\max }$ was significant $(p<0.002)$. Note different scales for $y$ axes in Figures 1 and 2. 
there is no effect of prenatal nutritional status on postnatal expression of IGF-I. However, when comparisons are made between SGA and AGA groups fed to repletion, it is seen that prenatal nutritional status can have a significant influence on IGF-I expression by $2 \mathrm{wk}$ of age. Comparisons between the $\mathrm{SGA}_{\max }$ and $\mathrm{AGA}_{\max }$ groups revealed that the $\mathrm{AGA}_{\max }$ group had a significantly higher hepatic concentration of IGF-I $(p<0.002)$ than did the SGA $_{\max }$ group (compare Figs. 1 and 2). The ad libitum food intake of the SGA animals was also much smaller than that of the AGA animals. For example, at $14 \mathrm{~d}$ of age, mean food intakes were $240 \pm 14$ and $366 \pm 19$ $\mathrm{g} / \mathrm{kg}^{0.67} / \mathrm{d}$ for the $\mathrm{SGA}_{\max }$ and $\mathrm{AGA}_{\max }$ groups, respectively $(p<0.001)$. Similarly, final body weight was significantly greater $(p<0.001)$ in the AGA animals than in the SGA animals (compare Tables 1 and 2).

Postnatal nutrition. Figure 3 shows that, when all the results for formula-fed animals are considered together, there is a close positive correlation between energy intake and hepatic IGF-I concentration $(r=0.77 ; p<$ $0.001)$. However, no such relation was found between energy intake and the concentration of plasma IGF-I $(r=$ $0.02 ; p>0.1$ ).

\section{DISCUSSION}

Major implications of the present investigation, with respect to early postnatal IGF-I expression, are con-

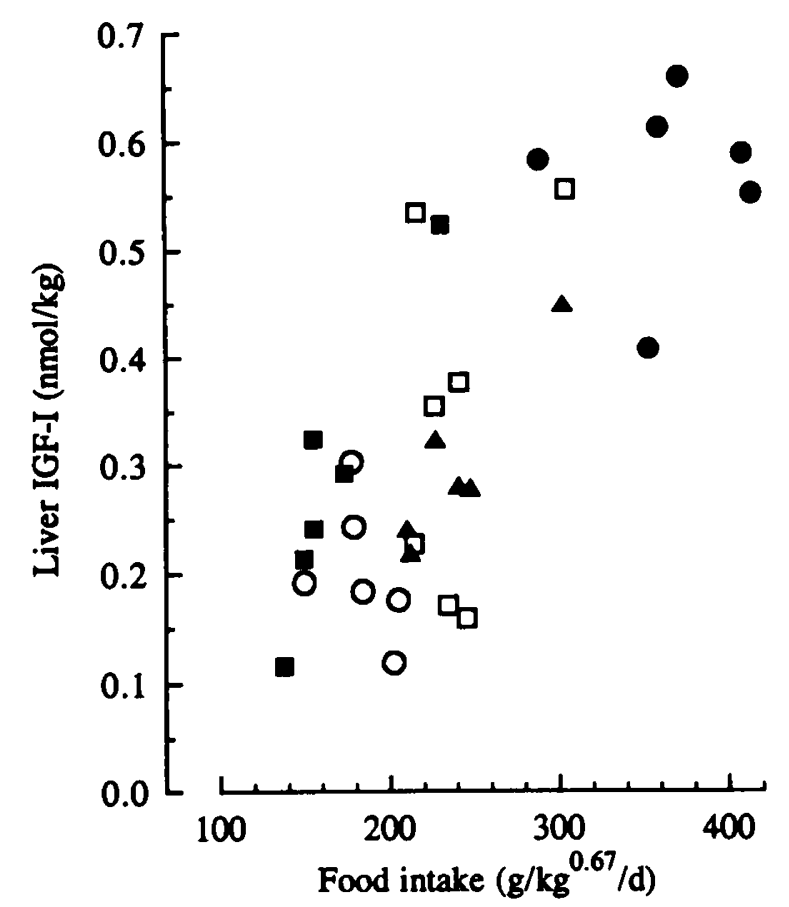

Figure 3. Relation between food intake and hepatic IGF-I content in SGA or AGA piglets fed a sow's milk replacement formula between 2 and $14 \mathrm{~d}$ of age. Measurements were made at $14 \mathrm{~d}$ in animals either fed to repletion at 6 -h intervals throughout the period of study $\left(\Delta, \mathrm{SGA}_{\max }\right.$; -, $\mathrm{AGA}_{\max }$ ); pair-fed the $\mathrm{SGA}_{\max }$ intake, either on the basis of metabolic body size or with the same absolute amount of food ( $\square$, AGA $_{\text {mbs }}$; and $\square, \mathrm{AGA}_{\text {abs }}$, respectively); or provided with $50 \%$ of the $\mathrm{AGA}_{\max }$ intake on the basis of metabolic body size $\left(\mathrm{O}, \mathrm{AGA}_{50 \%}\right)$. The correlation coefficient of 0.77 was statistically significant $(p<0.001)$. cerned with 1) the effects of birth weight and prenatal undernutrition on subsequent development; 2) the role of energy intake in the early postnatal period; and 3) the influence of maternal milk compared with a replacement milk formula.

Effects of birth weight and intrauterine growth retardation. In many studies of the human infant, a strong positive correlation has been observed between plasma IGF-I and birth weight $(12,16,34)$. In neonatal pigs, when comparisons are made within a breed, body weight and plasma IGF-I at birth are also positively correlated, with SGA piglets having significantly lower circulating levels of IGF-I than their AGA littermates (17). By contrast, Wang et al. (15) reported an inverse relation between plasma IGF-I and birth weight. This may have been related to the extremely wide variation observed in their subjects: the range of IGF-I in serum from the umbilical vein was $0.014-0.140 \mu \mathrm{mol} / \mathrm{L}(n=7)$ and 0.005 $0.133 \mu \mathrm{mol} / \mathrm{L}(n=83)$ for SGA and AGA subjects, respectively. It is not certain whether any of the infants had been fed between birth and sampling, because samples were collected between 0700 and $2300 \mathrm{~h}$ only to avoid the nocturnal peak in circulating IGFBP-1. Feeding of colostrum could have resulted in high levels of plasma IGF-I and, in addition, differences may have been related to genetics, because this can itself affect plasma levels of IGF-I in the neonate (17).

Interactions between nutritional status, insulin, and GH are involved in the regulation of plasma IGF-I concentration $(2,7)$. Low levels of circulating IGF-I in growth-retarded, SGA neonates are probably caused by prenatal undernutrition. Thus, studies of experimental growth retardation in fetal rats suggest that nutrient supply may be a limiting factor in the release of both insulin and IGF-I (35), and maternal fasting during late gestation has been found to reduce plasma IGF-I levels in fetal lambs (36). A difficulty with many studies is that it is not possible to differentiate between the relative importance, for example, of nutrition and insulin availability as modulating factors for IGF-I synthesis (37). The probability is that even when nutrient supply is optimal, insulin is obligatory for the maintenance of IGF synthesis and growth rate during late gestation (38). Although $\mathrm{GH}$ is known to play an important role in postnatal regulation of IGF-I synthesis, its precise role in prenatal growth is not clear. It is possible that this could vary between species and be related to the relative stage of maturity attained before birth (39). Even though plasma GH levels may not change, prenatal undernutrition could reduce GH receptor numbers, and hence the hepatic synthesis of IGF-I, in a manner similar to that occurring in postnatal undernutrition $(40,41)$.

As pointed out by Thiériot-Prévost et al. (16), studies of regulatory mechanisms controlling postnatal catch-up growth in SGA infants are necessary for determining guidelines in the obstetrical and pediatric management of fetal growth retardation. The present finding that at 2 wk of age there is no difference in either plasma or liver 
concentrations of IGF-I between SGA piglets and pairfed AGA littermates can be interpreted in two ways: either the SGA piglets have exhibited a catch-up phenomenon or the pair-fed AGA piglets have relatively low IGF-I levels because their food intake has been restricted to that of the SGA animals. A comparison between the results for studies 1 and 2 suggests that the second explanation is more likely to be valid, because when animals are fed to repletion, hepatic IGF-I concentration is approximately twice as great in AGA animals as in SGA animals. This indicates marked differences in IGF-I synthesis, and possibly also in hepatic storage mechanisms and kinetics of IGF-I release from liver to plasma. The present findings indicate that the ability of SGA animals to synthesize, and perhaps store and release, hepatic IGF-I is probably limited by their low ad libitum food intake. During the critical first $2 \mathrm{wk}$ of postnatal development, this limit on the capacity to consume food could therefore result in a permanent change in IGF-I status and hence in the growth and development of the SGA individual.

The extent to which hepatic IGFBP synthesis is affected by perinatal nutritional status also needs to be determined. Plasma concentrations of IGFBP are influenced by both chronic and acute changes in postnatal energy status, with IGFBP-3 increasing and IGFBP-2 decreasing when the availability of energy for growth is increased (31), and IGFBP-1 being inversely related to plasma levels of insulin and glucose (6). Despite a very wide variation in IGFBP-1 of newborn human infants, there was the suggestion of an inverse relation with birth weight, with high levels playing a potentially important role in inhibiting the action of IGF-I (15). Furthermore, in vitro studies on muscle from neonatal SGA rats have shown that, compared with muscle from AGA controls, the muscle does not increase its protein synthetic rate in response to IGF-I (42) and that the reduced growth potential of SGA infants could be related to differential secretions of IGF and IGFBP (43).

Role of energy intake in the early postnatal period. Comparison of the results for all formula-fed piglets indicated a close positive correlation between energy intake and hepatic IGF-I concentration (Fig. 3). This is consistent with findings in 2 -mo-old pigs, in which a $50 \%$ reduction in energy intake over a 5-wk period caused a significant reduction in hepatic IGF-I (20). Recent evidence using highly sensitive RNase protection assays suggests that this reduction in IGF-I concentration could be caused partly by changes in gene expression, with a reduction in hepatic IGF-I mRNA and potentially in synthesis of the IGF-I peptide occurring in animals with a low energy intake (44).

Unlike liver IGF-I concentration, there was no clear correlation between plasma IGF-I and energy intake in animals at $2 \mathrm{wk}$ of age. This is in marked contrast with older animals, in which circulating IGF-I is found to be related directly to the energy status of the individual (18, 19). In addition, there is a close positive correlation between plasma and liver concentrations of IGF-I in 2-mo-old animals (20). The reasons for these differences between neonatal and older animals remain to be established. However, the present finding of no difference in plasma IGF-I in one group of piglets consuming twice as much food as another could be related to differences in release from the tissues or clearance from the plasma, indicating the need for studies on the kinetics of IGF-I and its binding proteins.

Influence of maternal milk versus replacement formula feed. One of the most striking findings of the present investigation was the very much higher concentration of plasma IGF-I in piglets left with the sow compared with those fed a sow's milk replacement formula. This occurred despite there being no difference in liver IGF-I content between the two groups, and a number of suggestions can be advanced to explain this finding. The first possibility is that the primary source of IGF-I in animals left with the sow was the milk. This contrasts with the formula-fed animals, in which the liver would have been the major source of IGF-I. There is some discrepancy between studies as to the precise amount of IGF-I contained in the milk of different species $(29,45,46)$, and this could be related in part to differences in methodology. In general, however, IGF-I is present (21), although there tends to be large individual variation (47) and colostrum tends to contain more IGF-I than does mature milk. Previous investigations on milk composition have shown that sow's milk, and particularly colostrum, is high in IGF-I content (48). By contrast, the replacement formula used in the present study did not contain IGF-I, confirming the observation of Nagashima et al. (22) on cow's milk-based infant formulas.

Another possible explanation for the large difference in plasma IGF-I level between maternally fed and formulafed piglets is that there were differences in IGFBP profiles between the two groups. Such differences could affect the clearance and degradation rates of plasma IGF-I. A high proportion of circulating IGF is associated with IGFBP-3, and because its half-life is considerably increased when in the ternary complex, the steady state level of plasma IGF-I depends critically on IGFBP-3 (6). In young animals, there can also be a high level of IGFBP-2 in the circulation (31), and this may regulate IGF availability under conditions where the amount of ternary complex is not great enough to carry all the IGF in the circulation (6). Previous investigations of 2-mo-old piglets have demonstrated a positive relation between energy intake and IGFBP-3 and an inverse relation with IGFBP-2 (31). Although it was not possible to determine the food intake of the sow-fed piglets, their higher growth rates, compared with animals fed a replacement formula, suggest that they might have had a particularly high energy intake. This may have elevated IGFBP-3 and hence increased the half-life of circulating IGF-I. Furthermore, an increase in energy intake could increase hepatic IGF-I synthesis via an increase in $\mathrm{GH}$ receptors (41). A concomitant increase in hepatic IGF-I release, 
due to an elevation in insulin levels $(11,36)$, would then result in an elevation in plasma IGF-I while maintaining constant the hepatic IGF-I concentration. Clearly, future studies should be concerned with increasing our understanding of the mechanisms involved in synthesis and utilization of IGF-I in the perinatal period, and the role of milk IGF-I in determining growth rate also remains to be established.

Implications of the large difference in plasma IGF-I concentration between the maternally fed and formulafed neonates also need to be determined. The present results suggest that the IGF-I in maternal milk can be absorbed by neonatal piglets, and it may also act locally on the intestinal epithelial cells. Irrespective of whether the elevated IGF-I in maternally fed piglets results from differences in intestinal transport, hepatic synthesis and release, or IGFBP profiles, IGF-I is known to play an essential role in the growth and differentiation of many tissues. For example, it induces expression of specific genes in skeletal, cardiac, and smooth muscle (49), and many developmental changes also occur in the digestive and absorptive functions of the small intestine during neonatal life (50). The extent to which tissue development, including that of muscle and intestine, is affected by early postnatal nutrition therefore needs to be assessed.

Acknowledgment. The authors thank D. Brown, Statistics Group, The Babraham Institute, for statistical advice.

\section{REFERENCES}

1. Sara VR, Hall K 1990) Insulin-like growth factors and their binding proteins. Physiol Rev 70:591-614

2. Herington AC 1991 Insulin-like growth factors: biochemistry and physiology. In: Robertson DM, Herington AC (eds) Growth Factors in Endocrinology, Vol 5, No 4, Baillière's Clinical Endocrinology and Metabolism. Baillière Tindall, Philadelphia, pp 531-551

3. Wang HS, Chard T 1992 The role of insulin-like growth factor-I and insulinlike growth factor-binding protein-1 in the control of human fetal growth. $J$ Endocrinol 1.32:11-19

4. Froesch ER, Schmid C, Schwander J, Zapf J 1985 Actions of insulin-like growth factors. Annu Rev Physiol 47:443-467

5. Florini JR, Ewton DZ, Roof SL 1991 Insulin-like growth factor-I stimulates terminal myogenic differentiation by induction of myogenin gene expression. Mol Endocrinol 5:718-724

6. Baxter RC 1991 Physiological roles of IGF binding proteins. In: Spencer EM (ed) Modern Concepts of Insulin-like Growth Factors. Elsevier, New York, pp 371-380

7. Cohick WS, Clemmons DR 1993 The insulin-like growth factors. Annu Rev Physiol 55:131-153

8. Foley TPJ, De Philip R. Perricelli A, Miller A 1980 Low somatomedin activity in cord serum from infants with intrauterine growth retardation. J Pediatr 96:605-610

9. Daughaday WH, Parker KA, Borowsky S, Trivedi B, Kapadia M 1982 Measurement of somatomedin-related peptides in fetal, neonatal, and maternal rat serum by insulin-like growth factor (IGF) I radioimmunoassay, IGF-II radioreceptor assay (RRA) and multiplication-stimulating activity RRA after acid-ethanol extraction. Endocrinology 110:575-581

10. Gluckman PD, Barry TN 1988 Relationships between plasma concentrations of placental lactogen, insulin-like growth factors, metabolites and lamb size in late gestation ewes subject to nutritional supplementation and in their lambs at birth. Domest Anim Endocrinol 5:209-217

11. Breier BH, Gluckman PD, Bass JJ 1988 Plasma concentrations of insulin-like growth factor-I and insulin in the infant calf: ontogeny and influence of altered nutrition. J Endocrinol 119:43-50

12. Bennett A, Wilson DM, Liu F, Nagashima R, Rosenfeld RG, Hintz RL 1983 Levels of insulin-like growth factors $I$ and II in human cord blood. $J$ Clin Endocrinol Metab 57:609-612
13. Lee CY, Bazer FW, Etherton TD, Simmen FA 1991 Ontogeny of insulin-like growth factors (IGF-I and IGF-II) and IGF-binding proteins in porcine serum during fetal and postnatal development. Endocrinology 128:2336-2344

14. Deiber M, Chatelain P, Naville D, Putet G, Salle B 1989 Functional hypersomatotropism in small for gestational age (SGA) newborn infants. J Clin Endocrinol Metab 68:232-234

15. Wang HS, Lim J, English J, Irvine L, Chard T 1991 The concentration of insulin-like growth factor-I and insulin-like growth factor-binding protein-1 in human umbilical cord serum at delivery: relation to fetal weight. J Endocrinol 129:459_464

16. Thiériot-Prévost G, Boccara JF, Francoual C, Badoual J, Job JC 1988 Serum insulin-like growth factor 1 and serum growth-promoting activity during the first postnatal year in infants with intrauterine growth retardation. Pediatr Res 24:380-383

17. Herpin P, Le Dividich J, Duchamp C, Dauncey MJ 1992 Relation between plasma concentration of insulin-like growth factor-I and birth-weight in pigs. J Physiol (Lond) 446:276P(abstr)

18. Clemmons DR, Underwood LE 1991 Nutritional regulation of IGF-I and IGF binding proteins. Annu Rev Nutr 11:393-412

19. Dauncey MJ, Shakespear RA, Rudd BT, Ingram DL 1990 Variations in somatomedin-C/insulin-like growth factor-I associated with environmental temperature and nutrition. Horm Metab Res 22:261-264

20. Ma L, Burton KA, Saunders JC, Dauncey MJ 1992 Thermal and nutritional influences on tissue levels of insulin-like growth factor-I mRNA and peptide. J Therm Biol 17:89-85

21. Zumkeller W 1992 Relationship between insulin-like growth factor-I and -II and IGF-binding proteins in milk and the gastrointestinal tract: growth and development of the gut. J Pediatr Gastroenterol Nutr 15:357-369

22. Nagashima K, Itoh K, Kuroume T 1990 Levels of insulin-like growth factor I in full- and preterm human milk in comparison to levels in cow's milk and in milk formulas. Biol Neonate 58:343-346

23. Dauncey MJ 1991 Whole-body calorimetry in man and animals. Thermochim Acta 193:1-40

24. Tivey DR, Parkar A, Burton KA, Dauncey MJ 1992 Nutritional influences on circulating and hepatic concentrations of insulin-like growth factor-I in the neonatal pig. J Physiol (Lond) 446:298P(abstr)

25. Hayashi M, Ingram DL, Dauncey MJ 1987 Heat production and respiratory enzymes in normal and runt newborn piglets. Biol Neonate 51:324-331

26. Royston JP, Flecknell PA, Wootton R 1982 New evidence that the intrauterine growth-retarded piglet is a member of a discrete subpopulation. Biol Neonate 42:100-104

27. Wootton R, Flecknell PA, Royston JP, John M 1983 Intrauterine growth retardation detected in several species by non-normal birth weight distributions. J Reprod Fertil 69:659-663

28. Furlanetto RW, Underwood LE, Van Wyk JJ, D'Ercole AJ 1977 Estimation of somatomedin-C levels in normals and patients with pituitary disease by radioimmunoassay. J Clin Invest 60:648-657

29. Corps AN, Brown KD, Rees LH, Carr J, Prosser CG 1988 The insulin-like growth factor I content in human milk increases between early and full lactation. J Clin Endocrinol Metab 67:25-29

30. Prosser CG, Royle C, Fleet IR, Mepham TB 1991 The galactopoietic effect of bovine growth hormone in goats is associated with increased concentrations of insulin-like growth factor-I in milk and mammary tissue. J Endocrinol 128:457-463

31. Dauncey MJ, Rudd BT, White DA, Shakespear RA 1993 Regulation of insulin-like growth factor binding proteins in young growing animals by alteration of energy status. Growth Regul 3:198-207

32. Hua KM, Ord R, Kirk S, Li QJ, Hodgkinson SC, Spencer GSG, Molan PC, Bass JJ 1993 Regulation of plasma and tissue levels of insulin-like growth factor-I by nutrition and treatment with growth hormone in sheep. J Endocrinol 136:217-224

33. Welch BL 1987 The significance of the difference between two means when the population variances are unequal. Biometrika 29:350-362

34. Nishijima $M 1986$ Somatomedin-C as a fetal growth promoting factor and amino acid composition of cord blood in Japanese neonates. J Perinat Med $14: 163-169$

35. De Prins FA, Hill DJ, Fekete M, Robson DJ, Feillar NRS, Van Assche FA, Milner RDG 1984 Reduced plasma somatomedin activity during experimental growth retardation in the fetal rat. Pediatr Res 18:1100-1104

36. Basset NS, Oliver MH, Breier BH, Gluckman PD 1990 The effect of maternal starvation on plasma insulin-like growth factor 1 concentrations in the late gestation ovine fetus. Pediatr Res 27:401-404

37. Hill DJ, Hogg J 1989 Growth factors and the regulation of pre- and postnatal growth. In: Jones CT (ed) Perinatal Endocrinology, Vol 3, No 3, Baillière's Clinical Endocrinology and Metabolism. Baillière Tindall, Philadelphia, pp $579-625$

38. Fowden AL 1989 The role of insulin in prenatal growth. J Dev Physiol 12:173-182

39. Stewart F, Goode JA, Allen WR 1993 Growth hormone secretion in the horse: unusual pattern at birth and pulsatile secretion through to maturity. J Endocrinol 138:81-89

40. Gluckman PD, Breier BH 1989 The regulation of the growth hormone receptor. In: Heap RB, Prosser CG, Lamming GE (eds) Biotechnology in Growth Regulation. Butterworths, London, pp 27-33 
41. Dauncey MJ, Burton KA, White P, Harrison AP, Gilmour RS, Duchamp C, Cattaneo D 1994 Nutritional regulation of growth hormone receptor gene expression. FASEB J 8:81-88

42. Frampton RJ, Jonas HA, MacMahon RA, Larkins RG 1990 Failure of IGF-I to affect protein turnover in muscle from growth retarded rats. J Dev Physiol 13:125-133

43. Frampton RJ, Jonas HA, Larkins RG 1991 Increased secretion of insulin-like growth factor-binding proteins and decreased secretion of insulin-like growth factor-II by muscle from growth-retarded neonatal rats. J Endocrinol 130:33-42

44. Weller PA, Dickson MC, Huskisson NS, Dauncey MJ, Buttery PJ, Gilmour RS 1993 The porcine insulin-like growth factor-I gene: characterization and expression of alternate transcription sites. J Mol Endocrinol 11:201-211

45. Baxter RC, Zaltsman Z, Turtle JR 1984 Immunoreactive somatomedin-C insulin-like growth factor-I and its binding protein in human milk. J Clin Endocrinol Metab 58:955-959
46. Oda S, Satoh H, Sugawara T, Matsunaga N, Kuhara T, Katoh K, Shoji Y, Nihei A, Ohta M, Sasaki Y 1989 Insulin-like growth factor-I, GH, insulin and glucagon concentrations in bovine colostrum and in plasma of dairy cows and neonatal calves around parturition. Comp Biochem Physiol A 94:805-808

47. Simmen FA, Whang KY, Simmen RCM, Peterson GA, Bishop MD, Irvin KM 1990 Lactational variation and relationship to postnatal growth of insulin-like growth factor-I in mammary secretions from genetically diverse sows. Domest Anim Endocrinol 7:199-206

48. Simmen FA, Simmen RCM, Reinhart G 1988 Maternal and neonatal somatomedin C/insulin-like growth factor-I (IGF-I) and IGF binding proteins during early lactation in the pig. Dev Biol 130:16-27

49. Florini JR, Ewton DZ 1992 Induction of gene expression in muscle by the IGFs. Growth Regul 2:23-29

50. James PS, Smith MW, Tivey DR, Wilson TJG 1987 Epidermal growth factor selectively increases maltase and sucrase activities in neonatal piglet intestine. J Physiol (Lond) 393:583-594

\section{Announcement}

The 1st International Congress of Pediatric Sports Medicine will be held on September 4-10, 1994 in Vorau, Austria/Europe. For further information, please contact: Peter H. Schober, M.D., Department of Pediatric Surgery, Auenbruggerplatz 34, A-8036 LKH-Graz/Austria/Europe, Tel (0)316/385-3762, Fax (0)316/385-3775. 